\title{
Niewerbalne style komunikacyjne w przekładzie
}

\author{
Maria Mocarz-Kleindienst \\ Katolicki Uniwersytet Lubelski Jana Pawła II \\ momar@kul.pl
}

\begin{abstract}
Streszczenie
Komunikacja niewerbalna towarzyszy bezpośredniej ustnej komunikacji werbalnej. Niewerbalne środki komunikacyjne, konstytuujace style komunikacyjne kulturowo uwarunkowane, sa zjawiskiem, którego nie sposób pominać również w przekładzie. Przekład, w szczególności audiowizualny $i$ ustny, sprzyja poznawaniu niewerbalnych stylów, m.in. $w$ zakresie kinezyki, chronemiki, proksemiki, pantomimiki, haptyki pochodzacych z innych obszarów kulturowych. Oprócz funkcji poznawczej niewerbalne style komunikacyjne petniq funkcje wspomagajaca proces ttumaczenia (np. ustnego). Niekiedy niewerbalne środki komunikacyjne pomagaja zweryfikować jakość przettumaczonego przekazu werbalnego.
\end{abstract}

Stowa kluczowe: komunikacja niewerbalna, style komunikacyjne, kinezyka, chronemika, proksemika, pantomimika, haptyka

Abstract

Non-verbal communication styles in translation

Nonverbal communication accompanies direct oral verbal communication. The means of nonverbal communication, constituting culturally determined communication styles are a phenomenon which cannot be overlooked in translation. Translation, in particular audiovisual and interpretation, helps to become familiar with nonverbal styles, inter alia relating to kinesics, chronemics, proxemics, pantomimics, haptics from other spaces of culture. Apart from a cognitive function, nonverbal communication styles also serve an auxiliary function in the translation process (e.g. oral translation). Sometimes nonverbal communication styles help to verify the quality of translated verbal communication.

Keywords: nonverbal communication, communication styles, kinesics, chronemics, proxemics, pantomimics, haptics

\section{Wstęp}

Badania nad sygnałami niewerbalnymi były bardzo długo w badaniach nad komunikacją językową traktowane marginalnie. Zainteresowanie naukowe sygnałami pozawerbalnymi 
datuje się zasadniczo na okres po II wojnie światowej (Załazińska 2006: 73). Tymczasem badania dowodzą, że środki pozawerbalne stanowią dominantę bezpośredniej komunikacji międzyludzkiej holistycznie rozumianej (np. Nogalski, Jarocki 1998: 27-28). Według danych uczonych od 65 do nawet 90\% komunikacji odbywa się w sposób niewerbalny (Mehrabian 1968; Leathers [1997] 2007: 20). Tak wysoki udział sygnałów pozawerbalnych w procesie komunikacji interpersonalnej - głównie ustnej - można uzasadnić nieprzerwanym i jednocześnie otwartym charakterem ich nadawania i odbierania, w przeciwieństwie do sygnałów werbalnych. Wzrost zainteresowania elementami pozawerbalnymi (głównie gestami) nastąpił wraz z potrzebą wykorzystania takiej wiedzy jako środka retorycznego, służącego osiągnięciu skutecznej perswazji (Załazińska 2006: 73). Obecnie rola przekazów pozawerbalnych jest coraz wyraziściej eksplikowana w badaniach kulturoznawców antropologów (Hall [1959] 1987), semiotyków (Eco [1975] 2009), socjologów biznesowych (Gesteland [1996] 2000), psychologów (Głażewska, Kusio 2012), filmoznawców (Hendrykowski 2016, Hendrykowski 2017, Banaszkiewicz 1990), czy wreszcie istotnych w kontekście podjętego tematu badaniach językoznawczych oraz przekładoznawczych (np. Kiełbawska 2009, 2012, Załazińska 2006, Rennert 2008, Bühler 1986). Znaczny impuls do ich rozwoju dały procesy globalizacyjne, nowe technologie informacyjne oraz dominacja paradygmatu audiowizualności kultury, zapewniające bezpośrednią obserwację, analizę oraz ocenę zachowań pozawerbalnych. Powyższe przesłanki wzrostu zainteresowań komunikacją pozawerbalną ewokują potrzebę naukowego opisu tych zagadnień w kontekście przekładu. Celem zasadniczym niniejszych badań będzie wskazanie, w jaki sposób, w jakim zakresie oraz w jakich obszarach przekładu wykorzystywane są tzw. niewerbalne style komunikacyjne. Dopełnieniem prezentowanych - na tym etapie wstępnych i dość ogólnych - badań będzie krótka charakterystyka podstawowych komponentów oraz funkcji niewerbalnych stylów komunikacji w przekładzie.

\section{Pojęcie niewerbalnego stylu komunikacyjnego}

W tradycyjnym ujęciu styl jest definiowany np. jako „sposób ukształtowania tekstu w ramach tej samej zawartości komunikacyjnej w zależności od wyboru różnych środków synonimicznych należących do danej odmiany języka" (Polański 1999: 567). Zatem obszarem konstytuowania się stylu jest płaszczyzna tekstu - tu bowiem aktywizują się całe zespoły środków językowych wewnętrznie uporządkowanych, pozwalające dostrzec w danym tekście cechy typowe dla danego gatunku, typu tekstu i jednocześnie odróżniające go od innych 
wypowiedzi o podobnej lub identycznej zawartości informacyjnej. Jednocześnie, jak słusznie zauważa Andrzej Kudra, obecnie zaobserwować można odchodzenie od tradycyjnego, wyłącznie językowego rozumienia stylu na rzecz ujęcia holistycznego, interdyscyplinarnego, stanowiącego podstawę tzw. krytycznej analizy dyskursu, gdzie styl jest definiowany w kategoriach semiotycznych, wykraczających poza ramy wyłącznie werbalnych zachowań komunikacyjnych (Kudra 2011: 27). Takie podejście uzasadnia słuszność posługiwania się terminem styl również w odniesieniu do zespołu środków niewerbalnych jako immanentnych składników procesu komunikacji. Pojęcie stylu implikuje zastosowanie w określonym celu wewnętrznie uporządkowanego, skoordynowanego systemu znaków. Zagadnienie to zostanie przeanalizowane w kontekście przekładu, gdzie operacje translacyjne dokonywane są na całościowych komunikatach (pisemnych, ustnych lub mieszanych), nastawionych na osiągnięcie efektu komunikacyjnego. Uzasadnione zatem jest rozpatrywanie niewerbalnych środków językowych jako elementów konstytuujących właśnie niewerbalny styl komunikacji odnoszący się do komunikatu w całości. Zastosowanie danego stylu (zarówno werbalnego, jak i niewerbalnego) w celach komunikacyjnych zakłada jego rozpoznawalność w obrębie konkretnej wspólnoty kulturowej. Stąd też pod pojęciem niewerbalnego stylu komunikacyjnego rozumiem utrwalony społecznie i kulturowo system znaków niewerbalnych, zorganizowany w obrębie całościowego komunikatu (filmu, wypowiedzi ustnej, itp.) wspomagający lub samodzielnie konstytuujący proces komunikacyjny między czlonkami w obrębie danej społeczności językowo-kulturowej. Jest to system rozpoznawalny na mocy działających konwencji jako „mechanizmów stabilizujących wszelkie systemy semiotyczne" (Sawicka 2007: 279). Jest wykreowany przez daną wypowiedź i w niej się zawiera. Cechy konstytutywne danego stylu komunikacyjnego dają się wyodrębnić z bogatego repertuaru różnych środków dostępnych w świecie pozawerbalnych sygnałów. Użycie liczby mnogiej (style komunikacyjne) podyktowane jest zaangażowaniem różnorodnych środków, tworzących różne konstelacje i układy regulowane konwencją społeczną i tworzone na potrzeby różnych kontekstów komunikacji za pośrednictwem przekładu (o czym będzie mowa poniżej).

\section{Komponenty niewerbalnego stylu komunikacyjnego}

Przestrzeń komunikacji niewerbalnej wypełniają najczęściej współwystępujące ze sobą, skoordynowane elementy pozawerbalne, wyodrębnione na podstawie medium wizualnego. Są nimi: 
1) kinezyka, wykorzystująca tzw. emblematory, czyli ruchy ciała, gesty. Generalnie cechuje je wysoki stopień uniwersalności, jednak arbitralny charakter tych znaków ewokuje niekiedy różnice $\mathrm{w}$ przekazywanych znaczeniach. Stąd też zbytnie przekonanie o ich uniwersalizmie może być źródłem nieporozumień, czy wręcz zaburzeń komunikacyjnych. Przykładowe pukanie się w skroń może być odebrane w jednej kulturze (we Francji, Włoszech, Niemczech) jako przekaz ,jesteś idiotą”, w innych natomiast (w Hiszpanii, Wielkiej Brytanii) ,ale jestem bystry”. W Niemczech z kolei policja może nawet ukarać za ten gest (tzw. Vogelzeigen) mandatem (Gesteland [1996] 2000: 84). Z reguły emblematory mają swoje werbalne odpowiedniki, np. kiwnięcie głową na znak zgody może być zastąpione wyrazem „tak” lub ,zgadzam się”, ewentualnie innymi o zbliżonych zakresach znaczeń.

2) mimika wraz $\mathrm{z}$ okulestyką, obejmującą intensywność i rodzaj ekspresji twarzy: przyzwolenie na okazywanie emocji lub przeciwnie - kontrolowanie ich, nawiązywanie lub unikanie kontaktu wzrokowego. Mimika, jak słusznie zauważa Karina Banaszkiewicz, jest stosunkowo łatwo dekodowana przez odbiorcę. Jest to spowodowane naturą odruchów ją tworzących jako najczęściej niekontrolowanych przez naszą świadomość, a zatem zupełnie naturalnych zachowań (Banaszkiewicz 1990: 111). W kulturze Zachodu np. nawiązanie kontaktu wzrokowego jest warunkiem koniecznym do zaistnienia relacji interpersonalnej. Kontakt wzrokowy informuje, czy komunikacja jest w ogóle możliwa. W kulturze Wschodu tymczasem „szczere spojrzenie w oczy” jest postrzegane jako brak szacunku, ograniczone są również środki ekspresji twarzy. Podobnie osoby wywodzące się z kręgu kultury anglosaskiej częściej niż np. Latynosi świadomie kontrolują wyraz swoich twarzy (Leathers [1997] 2007: $53)$.

3) proksemika, skupiona na normach regulujących odległości między rozmówcami. Klasyczna klasyfikacja przestrzeni proksemicznych opracowana przez Edwarda Halla obejmuje cztery strefy dystansu komunikacyjnego: 1) wewnętrzną i zewnętrzną strefę intymną (do $45 \mathrm{~cm}$ dystansu między interlokutorami), 2) osobistą (45 cm - 1,2 m), społeczną (1,2 - 3,6 m) oraz publiczną (powyżej 3,6 m). Normy te mają charakter zmienny, są uwarunkowane kulturowo, co w praktyce oznacza, że odległości te w innych kulturach, np. Dalekiego Wschodu ulegają skróceniu (Hall [1959] 1987: 213-214).

4) haptyka, oparta na dotyku i regulująca zasady przyzwolenia na dotyk, długość, intensywność i częstotliwość (Jaroszewska 2014: 36-37). Dotyk w postaci np. uścisku dłoni, poklepywania po plecach czy obejmowania drugiej osoby w trudnych sytuacjach życiowych 
stanowi sygnał o bardzo dużej sile oddziaływania. W różnych kulturach istnieją różne normy społeczne, które regulują akceptowany obszar i liczbę dotyków w zależności od charakteru związku interpersonalnego (Jaroszewska 2014: 38).

5) chronemika, wykorzystująca czas jako sygnał komunikacyjny, np. punktualność, czas oczekiwania, czas trwania spotkania, itp. Pozwala określić, w jaki sposób członkowie różnych kultury odnoszą się do czasu. Różnorodność w podejściu do tych kategorii stała się podstawą wyróżnienia przez Edwarda Halla kultur monochronicznych (np. Japonia, germańskie kraje europejskie), przywiązujących dużą wagę do czasu, punktualności, nieprzekraczalności wyznaczonych terminów oraz kultur polichronicznych (kraje arabskie, kraje latynoamerykańskie oraz basenu Morza Śródziemnego), w których kładzie się znacznie mniejszy nacisk na punktualność.

6) paralangue - w tym przypadku niewerbalny styl komunikacyjny jest kształtowany również przez komponenty audialne (parawerbalne), spośród których najbardziej rozpoznawalnymi są barwa i intensywność głosu, zasięg dźwięku, ton wypowiedzi. Głośny ton rozmowy nie jest mile widziany w krajach Bliskiego Wschodu, gdzie miarą kultury osobistej osoby jest stonowana wypowiedź. W krajach arabskich i basenu Morza Śródziemnego tymczasem głośny ton wypowiedzi jest zupełnie naturalnym zjawiskiem dalekim od negatywnego wartościowania (Nogalski, Jarocki 1998: 55).

Wielość i różnorodność stylów komunikacyjnych wynika ze względnego, arbitralnego charakteru znaczeń ich komponentów, co znalazło potwierdzenie w przytoczonych wcześniej egzemplifikacjach. Owa różnorodność niewerbalnych stylów komunikacyjnych, mających charakter umowy społecznej legła u podstaw propozycji klasyfikacji kultur, np. kultury niskoi wysokokontekstowe (według typologii Edwarda Halla) czy kultury ekspresyjne oraz powściągliwe (w koncepcji Richarda G. Gestelanda). W pierwszej propozycji typologii - w kulturach niskokontekstowych - komunikacja niewerbalna ma dużo mniejsze znaczenie niż w kulturach wysokokontekstowych, w których przekaz werbalny często jest mało precyzyjny (Hall [1959] 1987). Z kolei w koncepcji Gestelanda kultury powściągliwe są kojarzone z ograniczonym zasobem używania gestów, mimiki, uporządkowanym tokiem wypowiedzi, podczas gdy w kulturach ekspresyjnych spotykamy znacznie więcej przejawów gestykulacji, dotyku, wypowiedzi są donioślejsze, przerywane (Gesteland [1996] 2000: 68 i in.). Zatem wielość niewerbalnych stylów komunikacyjnych dodatkowo jest pochodną różnorodności przestrzeni kulturowych, w których one funkcjonują. 


\section{Sfery przekładu aktywizujące niewerbalne style komunikacyjne}

Posługując się pojęciem przekład, mam w tym miejscu na myśli dwojakie, utrwalone w tradycji przekładoznawczej znaczenie tego pojęcia: jako procesu oraz produktu takiego procesu w postaci tekstu pisemnego, ustnego czy audiowizualnego. Pierwszą z takich sfer jest niewątpliwie przekład filmowy (audiowizualny) jako przekaz intersemiotyczny z udziałem różnych kodów i znaków, pozostających w związku interakcyjnym między sobą. Sfera pozawerbalna zostaje $\mathrm{w}$ tym przypadku zaktywizowana na potrzeby, po pierwsze, praktyki (sprawnego przebiegu) procesu przekładu, zatem przydatna thumaczowi, po drugie, odbioru przekładu. Zarówno w pierwszym, jak i w drugim przypadku punktem odniesienia w analizie stylów niewerbalnych w tym obszarze przekładu jest obraz. To właśnie w warstwie wizualnej thumacz dostrzega style zachowań niewerbalnych, które pomagają mu $\mathrm{w}$ doborze środków leksykalnych oraz strategii thumaczeniowej, a niekiedy nawet taki dobór determinują. Z kolei odbiorcy takiego przekładu audiowizualnego kontakt $\mathrm{z}$ niewerbalnymi stylami dostarcza informacji o innych, odmiennych stylach komunikacyjnych, których poznanie jest warunkiem koniecznym skutecznej komunikacji interkulturowej (przykłady z konkretnych filmów zostały umieszczone we wcześniejszej pracy (Mocarz-Kleindienst 2017: 147), będącej wstępną wersją prezentowanych badań).

Kolejną sferą, gdzie dokonuje się aktywizacja niewerbalnych stylów komunikacyjnych, jest przekład ustny. Tu niewerbalne style komunikacyjne funkcjonują w następujących płaszczyznach komunikacji: między nadawcą a thumaczem, tłumaczem a odbiorcami komunikatu w języku przekładu, niekiedy także między tłumaczami. Oczywiście nie wszystkie formy przekładu ustnego mogą w jednakowym stopniu wykorzystywać style pozawerbalne. Pewne ograniczenia niesie tu przekład kabinowy, podczas którego tłumacz ma utrudniony bezpośredni wzrokowy kontakt w prelegentami, mimo iż widzi sylwetkę i twarz prelegenta, dzięki zainstalowanym w kabinach monitorom. Warunki pracy tłumacza symultanicznego pozwalają mu obserwować zachowania pozawerbalne nadawców, ale już bezpośrednia interakcja pozawerbalna między nimi jest ograniczona, chociaż nie niemożliwa. Warto w tym miejscu zasygnalizować inny układ uczestników komunikacji z zastosowaniem techniki tłumaczenia kabinowego, gdzie sygnały pozawerbalne są obecne. Układ taki powstaje w samej kabinie, w której z reguły obecnych jest dwóch tłumaczy i to oni mogą komunikować się ze sobą, wykorzystując mimikę, gesty porozumiewawcze i wskazujące np. na sporządzoną krótką notatkę. W innych formach przekładu ustnego, jakimi są np. przekład środowiskowy czy przekład konferencyjny z zastosowaniem formuły konsekutywnej, udział komponentów 
pozawerbalnych jest bardzo pomocny w skutecznej komunikacji dwujęzycznej, wpływającym na jej jakość, o czym będzie mowa w kolejnym podrozdziale: Funkcje niewerbalnych stylów komunikacji w przekładzie.

Dodatkową przestrzenią, gdzie niewerbalne style komunikacyjne w żaden sposób nie mogą być pominięte, jest audiodeskrypcja. Jako istotna część komunikacji międzyludzkiej obrazy niewerbalne niedostępne percepcji osobom z dysfunkcją wzroku są dostrzegane przez tłumaczy audiodeskryptorów i przenoszone na płaszczyznę zwięzłego przekazu werbalnego. W danym przypadku niewerbalne style komunikacyjne są dostępne dla odbiorców jedynie w sposób pośredni.

\section{Funkcje niewerbalnych stylów komunikacji w przekładzie}

Dale G. Leathers wyróżnia następujące funkcje komunikacyjne, realizowane przy zastosowaniu sygnałów niewerbalnych: 1) przekazywanie informacji, 2) regulowanie interakcji, 3) wyrażanie emocji, 4) tworzenie metakomunikacji, 5) kontrolowanie sytuacji społecznych oraz 6) kształtowanie i kierowanie wrażeniami (Leathers [1997] 2007: 35). Po przeanalizowaniu różnych kontekstów zastosowań niewerbalnych stylów komunikacyjnych na potrzeby przekładu, proponuję następującą, dodam, wstępną typologię funkcji niewerbalnych stylów komunikacyjnych. Zaznaczam przy tym, że mają one charakter względny, arbitralny, są ustalane w zależności od kategorii odbiorcy (tłumacza czy też odbiorcy przekładu), na potrzeby „użytkownika” danego stylu komunikacyjnego. W dalszej części skupię na omówieniu najważniejszych z nich:

1) Funkcja poznawcza - wartość poznawczą stylów komunikacji pozawerbalnej w przekładzie oferuje przede wszystkim materiał filmowy, w którym prezentowane są kultury odległe jego finalnemu odbiorcy. Im większa różnica pomiędzy kulturami, tym wartość poznawcza elementów pozawerbalnych (w zakresie np. gestykulacji, dotyku, dystansu przestrzennego) jest większa (np. zetknięcie kultury niskokontekstowej z wysokokontekstową - według koncepcji Halla, czy powściągliwej z ekspresyjną, stosując koncepcję Gestelanda). Kontrast pomiędzy kulturą odbiorcy a prezentowaną na ekranie inną kulturą przyciąga uwagę, czyni fabułę filmu bardziej interesującą. Niekiedy efekt poznawczy poprzedza efekt zaskoczenia, a nawet szoku kulturowego. Wartość poznawczą wzmacniają zabiegi zetknięcia dwóch lub niekiedy więcej kultur, a więc i stylów komunikacyjnych w przestrzeni jednego filmu, w szczególności w sytuacjach, gdy dochodzi do bezpośredniej konfrontacji, w której w 
sposób naturalny ujawniają się niewerbalne style komunikacyjne uczestników takiej komunikacji interkulturowej. Osiągnięcie efektu poznawczego jest uzależnione od spostrzegawczości, uwagi, wrażliwości na odmienne formy komunikacji wśród odbiorców. Wyszczególnienie właśnie funkcji poznawczej jest słuszne - w moim przekonaniu - dzięki założeniu, że widz, decydujący się na obejrzenie obcojęzycznego filmu w przekładzie jest świadomy innych treści kulturowych, nastawiony na poznanie tej inności, również w zakresie odmiennych stylów komunikacyjnych. W charakterze przykładu ilustrującego omawiane zjawisko wykorzystam amerykański film pt. Między słowami (ang. Lost in translation) w reżyserii Sofii Coppoli. Widzowie polscy mają możliwość przyjrzenia się odmiennym, kulturowo odległym obrazom, reprezentatywnym dla kultury japońskiej. W tokijskiej rzeczywistości przypadkiem w barze spotyka się dwoje Amerykanów (w głównych rolach Bill Murray i Scarlett Johansson), zderzających się z odmiennymi wzorcami kulturowymi i zarazem przeżywających fascynację egzotyką japońskiej stolicy. Kilka scen z filmu w sposób perfekcyjny prezentuje odmienność kulturową Japończyków w zakresie zachowań niewerbalnych. Pierwszy z przykładów dotyczy sytuacji w windzie, kiedy amerykańscy bohaterowie filmu wsiadają do niej, są zdumieni milczącą postawą jadących w niej Japończyków. W windzie panuje cisza. Widz nie dostrzeże w niej uśmiechów na twarzach. Osoby znajdujące się w windzie unikają kontaktu wzrokowego, są ustawione w rzędach, nie zaś w pozycji vis-a-vis, typowej dla zachowań europejskich.

2) Funkcja regulacyjna konwersacji - sygnały niewerbalne, zwane regulatorami, mogą być użyte do regulacji płynności, długości konwersacji lub komunikacji z wykorzystaniem przekładu. Taką funkcję można przypisać czynnościom nawiązywania kontaktu wzrokowego między nadawcą tekstu mówionego w języku wyjściowym oraz osobą thumacza. Ruch głową, wskazanie ręką tegoż nadawcy w stronę thumacza może oznaczać przerwę w nadawaniu przez niego komunikatu i oddanie głosu tłumaczowi. Funkcja regulacyjna aktywizuje się w interakcji nadawcy i tłumacza ustnego w sytuacji, gdy mają oni kontakt wzrokowy, także w tłumaczeniu symultanicznym, np. między tłumaczami, o czym była mowa powyżej.

3) Funkcja ekspresywno-impresywna - często współwystępuje z funkcją wcześniejszą w sytuacji tłumaczeń ustnych konsekutywnych. Przykładowo gesty mrugnięcia tłumacza skierowane $\mathrm{w}$ stronę mówiącego oznaczają zrozumienie przez niego usłyszanych treści. Podobnie wymiana spojrzeń informuje obie strony o wzajemnym zrozumieniu (Kiełbawska 200: 82-89). Gesty wykorzystywane w realizacji tej funkcji czasami są nazywane alteradaptatorami, tj. gestami relacyjnymi (Antas 2001). Z racji tego, że komunikacja 
niewerbalna zarządza naszymi kontaktami tu i teraz, na bieżąco, jak zauważa Patterson (Patterson [2010] 2011: 21), procesy nadawcze i odbiorcze pracują jednocześnie, dlatego siła ekspresji i jednocześnie impresji są traktowane w niniejszych badaniach jako zjawiska nierozłączne.

4) Funkcja substytucji (zastępowania) - istotna $\mathrm{z}$ punktu widzenia działań translatorskich tłumacza filmowego, również ustnego. Niektóre elementy niewerbalnych stylów komunikacji są tak reprezentatywne dla modeli zachowań kulturowych (np. powitania, przebieg konwersacji, pożegnania), że tłumacze, w szczególności filmowi, rezygnują wskutek ograniczeń czasowych lub przestrzennych $-\mathrm{z}$ paralelnego przekazu werbalnego, obecnego w wersji oryginalnej listy dialogowej i wyrażającego tożsame treści rytualne (typu dzień dobry, hallo, stucham, do widzenia). Analogicznie tłumacz ustny, widząc wykonywane przez prelegenta gesty i towarzyszące im frazy werbalne może zrezygnować z thumaczenia formuł towarzyszącym tym znakom niewerbalnym.

5) Funkcja weryfikująca - ta funkcja jest obecna w kontekście odbioru ustnego tekstu tłumaczonego w sytuacji, gdy tłumacz rozpoznaje, a nawet przewiduje zachowania niewerbalne prelegenta (np. w trakcie rozpraw w sądzie, zeznań na policji). Z komponentem weryfikacyjnym mamy do czynienia także wtedy, kiedy odbiorcy zachowują kontakt wzrokowy z tłumaczem, mogą obserwować jego ruchy, gestykulację, uważnie wsłuchując się w siłę głosu tworzonego przez niego komunikatu. Wnikliwi słuchacze są w stanie dostrzec niepewność, zawahania tłumacza lub reakcje zgoła odwrotne: zdecydowanie, przekonanie o słuszności podejmowanych decyzji translatorskich. Wyprostowana sylwetka tłumacza na pewno będzie sygnałem jego pewności siebie, skierowanie w stronę słuchaczy - sygnałem jego pozytywnego nastawienia do publiczności. Są to podstawowe sposoby kreowania wizerunku tłumacza, oceny jakości jego pracy, co potwierdzają np. badania ankietowe przeprowadzone przez H. Bühler. Wykazano w nich, że następujące parametry: przyjemny głos, płynność wypowiedzi czy silny akcent (zatem sygnały parawerbalne) są istotne w ocenie jakości pracy tłumacza ustnego (oczywiście pierwszoplanową rolę odgrywają tu komponenty językowe, jak np. spójność wypowiedzi, zgodność z treścią oryginału czy zastosowanie odpowiedniego stylu, itd.) (Bühler 1986).

6) Funkcja konkretyzująca - użycie odpowiedniej intonacji, barwy głosu i innych sygnałów parajęzykowych skutecznie może eliminować wieloznaczność sygnałów werbalnych wyrażających różnorodne emocje (typu oh!, o-o-o!). Ta funkcja wspomaga zarówno sam 
sposób percepcji tekstu przez odbiorców przekładu, jak i przyspiesza pracę thumacza, np. podczas tłumaczenia dialogów filmowych. Wyraźnie sprofilowane brzmieniowo i przez to jednoznaczne w swej semantyce wykrzykniki często są pomijane w wersjach napisowych.

\section{Wnioski}

Omówione pokrótce najistotniejsze komponenty stylów niewerbalnych oraz ich wybrane funkcje pokazują istotę i doniosłość sygnałów pozawerbalnych w komunikacji międzyjęzykowej i międzykulturowej zarazem. Ich różnorodność pozwala mówić o co najmniej dwóch perspektywach odbioru: perspektywie finalnego odbiorcy przekładu oraz perspektywie samego thumacza. W pierwszym przypadku komunikacja niewerbalna pełni funkcję poznawczą, weryfikującą, niekiedy konkretyzującą, w drugim z kolei - sygnały pozawerbalne pełnią przede wszystkim funkcję regulacyjną konwersacji, ekspresywnoimpresywną, w mniejszym stopniu poznawczą czy substytucji. Zaprezentowane komponenty stylu niewerbalnego pokazujące ich zróżnicowanie znaczeniowe uwarunkowane kulturowo dowodzą potrzeby poznania zasad komunikacji pozawerbalnej. Zapoznanie się z kulturową specyfiką zachowań niewerbalnych jest bowiem warunkiem koniecznym do zaistnienia skutecznej komunikacji międzykulturowej. Niewerbalne środki komunikacyjne, konstytuujące - poprzez wysoką częstotliwość i konsekwencję ich stosowania - style komunikacyjne kulturowo uwarunkowane, są zjawiskiem, którego nie sposób pominąć w przekładzie.

\section{Bibliografia}

Antas, Jolanta (2000) „Co mówią ręce. Wprowadzenie do komunikacji niewerbalnej”. [W:] Renata Przybylska, Wiesław Przyczyna (red.), Retoryka dziś. Teoria i praktyka. Kraków: Poligrafia Salezjańska; 437-459.

Banaszkiewicz, Karina (1990) „Kinezyka filmu czy kinezyka w filmie?”. [W:] Andrzej Gwóźdź (red.), Kino: gest - ciało - ruch. Film w perspektywie systemów komunikowania niewerbalnego. Wrocław: Wydawnictwo Centralnego Programu Badań Podstawowych; 99-120.

Bühler, Hildegund (1986) „Linguistic (semantic) and extra-linguistic (pragmatic) criteria for the evaluation of conference interpretation and interpreters". Multilingua, 5 (4); 231-235 [pobrane z https://doi.org/10.1515/mult.1986.5.4.231. Data ostatniego dostępu: 23.01.2018]. 
Eco, Umberto ([1975] 2009) Teoria semiotyki [Trattato di semiotica generale. Milano: Bompiani] (tłum.) Maciej Czerwiński. Kraków: Wydawnictwo Uniwersytetu Jagiellońskiego. Gesteland, Richard G. ([1996] 2000) Różnice kulturowe a zachowania w biznesie [Crosscultural Business Behavior. Copenhagen: Copenhagen Business School Press]. Warszawa: Wydawnictwo Naukowe PWN.

Głażewska, Ewa, Urszula Kusio (2012) Komunikacja niewerbalna. Płeć i kultura. Wybór zagadnień. Lublin: Wydawnictwo Uniwersytetu Marii Curie-Skłodowskiej.

Hall, Edward ([1959] 1987) Bezgtośny język. [The Silent Language. New York: Doubleday] (tłum.) Roman Zimand, Alicja Skarbińska. Warszawa: Państwowy Instytut Wydawniczy.

Hendrykowski, Marek (2017) Semiotyka twarzy. Poznań: Wydawnictwo Naukowe UAM.

Hendrykowski, Marek (2016) Proksemika: studia z semiotyki i antropologii kultury. Poznań: Wydawnictwo Naukowe UAM.

Jaroszewska, Emilia (2014) „Różnice kulturowe jako bariera w komunikowaniu masowym i interpersonalnym". [W:] Janusz W. Adamowski, Alicja Jaskiernia (red.), Międzykulturowe aspekty działalności mediów w epoce globalizacji, Warszawa: Oficyna Wydawnicza ASPRA-JR; 23-46.

Kiełbawska, Amelia (2012) Funkcje komunikacji niewerbalnej w interakcji mówcy i tłumacza. Kraków: Uniwersitas.

Kiełbawska, Amelia (2009) „Funkcje komunikacji niewerbalnej w świetle językoznawstwa”. [W:] Agnieszka Łaba (red.), Współczesne teorie komunikacji 2, Wrocław: Oficyna Wydawnicza Atut; 133-148.

Kudra, Andrzej (2011) „Idiolektostylem w mur, czyli o idiolekcie, idiostylu i krytycznej analizie dyskursu - na przykładzie felietonów Krzysztofa Skiby w tygodniku „Wprost””. Acta Universitatis Lodzensis. Folia Litteraria Polonica. T. 14 (1); 27-34.

Leathers, Dale G. ([1997] 2007) Komunikacja niewerbalna. Zasady $i$ zastosowania. [Successful nonverbal communication. Principles and applicatications. London: Pearson Education] (tłum.) Magdalena Trzcińska. Warszawa: Wydawnictwo Naukowe PWN.

Mehrabian, Albert (1968) „Communication without words”. Psychology Today, 2; 51-51.

Mocarz-Kleindienst, Maria (2017) „Невербальные коммуникативные стили в переводе ”. [W:] Emma Arhangelska, Julija Rastorgujeva, Dace Šostaka (ed.) Multidimensional Translation: from Science to Art. Riga: RETORIKA A.; 139-154.

Nogalski, Bogdan, Jarocki, Paweł (1998) Komunikacja niewerbalna $w$ negocjacjach międzynarodowych. Bydgoszcz: Oficyna Wydawnicza Ośrodka Postępu Organizacyjnego Sp. z o.o. 
Patterson, Miles. L. ([2010] 2011) Więcej niż słowa. Potęga komunikacji niewerbalnej. [More than words: The power of nonverbal communication. Bellcaire d'Empordà: Editorial Aresta S.C.] (tłum.) Mirosław Przylipiak. Sopot: Gdańskie Wydawnictwo Psychologiczne.

Polański, Kazimierz (1999) Encyklopedia językoznawstwa ogólnego. Warszawa: Zakład Narodowy im. Ossolińskich.

Rennert, Sylvi (2008) „Visual Input in Simultaneous Interpeting”. Meta, Vol.53 [pobrane z https://www.erudit.org/en/journals/meta/2008-v53-n1-meta2114/017983ar.pdf. Data ostatniego dostępu: 23.01.2018].

Sawicka, Grażyna (2007) „Dynamika reklamy jako stylu komunikacyjnego”. [W:] Grzegorz Szpila (red.), Język polski XXI wieku: analizy, oceny, perspektywy. Język a komunikacja 17. Kraków: Tertium; 275-283.

Załazińska, Aneta (2006) Niewerbalna struktura dialogu. Kraków: Universitas. 